\title{
Tempering Process Optimization in Sae 9254 Wires Through Generalized Reduced Gradient, Genetic Algorithms and Simulated Annealing
}

\author{
Cristie Diego Pimenta ${ }^{1}$, Messias Borges Silva ${ }^{1}$, Rosinei Batista Ribeiro ${ }^{1}$, \\ Rose Lima de Morais Campos ${ }^{1}$, Walfredo Ribeiro de Campos Junior ${ }^{2}$, Jorge Luiz Rosa ${ }^{1}$ \\ ${ }^{1}$ Department of Production, University of Guaratinguetá (Feg-Unesp), São Paulo, Brazil \\ ${ }^{2}$ Department of Marketing, College ESPM, São Paulo, Brazil
}

\section{Email address:}

pimentadiego@yahoo.com.br (C. D. Pimenta), messias.silva@feg.unesp.br (M. B. Silva), rosinei1971@gmail.com (R. B. Ribeiro), campos_rose@ig.com.br (R. L. D. M. Campos), wrcampos@gmail.com (W. R. D. C. Junior), jorge.luizrosa@hotmail.com (J. L. Rosa)

\section{To cite this article:}

Cristie Diego Pimenta, Messias Borges Silva, Rosinei Batista Ribeiro, Rose Lima de Morais Campos, Walfredo Ribeiro de Campos Junior, Jorge Luiz Rosa. Tempering Process Optimization in Sae 9254 Wires Through Generalized Reduced Gradient, Genetic Algorithms and Simulated Annealing. American Journal of Theoretical and Applied Statistics. Vol. 5, No. 1, 2016, pp. $27-38$.

doi: $10.11648 /$ j.ajtas.20160501.15

\begin{abstract}
The purpose of this work was the creation of a statistical modeling able to replace the process used to setup of the ovens of the quench hardening and tempering that is traditionally accomplished through adjustments made based on the results of mechanical properties as tested in laboratory and required in customer specifications. We sought to understand the influence of the input variables (factors) on the mechanical properties tensile strength and hardness, in SAE 9254 draw steel wires, with diameters $2.00 \mathrm{~mm}$ and $6.50 \mathrm{~mm}$, used in the manufacture of valve springs and clutch for automobile tracking. Were investigated the input variables of the process speed and tempering temperature. Design of Experiments with block Analysis, Quadratic Multiple Regression, Analysis of Variance (ANOVA) and Response Surface Methodology (RSM). For the optimization of statistical models were used the Generalized Reduced Gradient methods (GRG), Genetic Algorithm (AG) and the Meta-heuristics Simulated Annealing (SA). The results revealed that all variables considered have significant influence and models obtained were validated using appropriate statistical methods. This new modeling and its optimization, if properly implemented and enforced, could lead scientific advances which would provide the automation of this process, and consequently cause great impact on increasing productivity and product quality.
\end{abstract}

Keywords: Heat Treatment, Generalized Reduced Gradient, Design of Experiments, Response Surface Method, Genetic Algorithms, Meta-Heuristic

\section{Introduction}

The ferrous alloys, especially carbon and special steels, have fundamental importance in mechanical construction, due to its properties of strength, among others. The job of these alloys is very diverse and their selection, in General, very carefully. To produce them with mechanical properties that meet the requirements of applications originally envisaged, it is necessary that the main parameters of the process are well known and adjusted properly.

The requirements of special steels market, led by manufacturers of automobiles and spare parts, require steelmakers to produce steels that meet the requirements related to mechanical properties obtained by means of heat treatment quenching and tempering.

Grosselle et al. (2010) studied the influence of process parameters on the properties of aluminium alloys fused and this methodology was employed successfully by using the design of experiments and analysis of variance to establish the relationship between four parameters of the casting process, in which three of them were tested on two levels and one with three levels, for studies on microstructure and mechanical properties in the manufacture of engine blocks. With the implementation of the experimental planning held, it was possible to consider the relationship between variables and understand the contribution of each variable, or their interactions, on the desired results. 
Gunasegaram et al. (2009) studied the process parameters that contribute to the formation of shrinkage defects in an aluminum cast of complex geometry, produced by the permanent mold process. The experiment Design was supported by numerical simulations, having studied the behavior of five factors at two levels each. The solution has led to a reduction of 13 (percent) product scrap level.

Among the most widely used testing to measure the hardenability the Jominy methods and the method DI (diameter ideal critic), developed by the Caterpillar company (manufacturer of machines), which is based on multiple regression of the steel chemical elements to estimate the depth of quenching and thus correlate it with the mechanical properties hardness and tensile strength limit (YAMADA, 2007). However, the technique is used most often in tempered steel with quenching 50 (percent) and cannot meet the need of the process in question, because in the process studied is performed to temper in 100 (percent), that is, the material is hardened the surface to the core.

Blondeau et al. (2000) showed the application of mathematical models in regressive prediction of mechanical properties of steel bars. Although the model have shown good results in bars, the research in question comes to drawn wires that have very different characteristics.

Hodgson and Gibbs (1992) have shown the influence of the elements carbon (C) and manganese (Mn) in the mechanical properties of steel bars, as well as mathematical modeling for this process, also restricted the steel bars.

Ribeiro (2006) stated that the mechanical properties of SAE 4140 steel were influenced by tempering parameters, in particular for the temperature and time of heat treatment.

According to Camarão (1998), the mechanical properties are totally influenced by the temperature of quenching and Stein (2004) found that the rapid austenitising sensibly affects mechanical properties and microstructure of steels with carbon content above 0.4 (percent), in quenched and tempered condition, as well as, studied the effect of austenitizing quick on the mechanical properties of 1045 steel, hardened and tempered. Experimental variables used were: austenitising temperatures (soak times and intervals of tempering) and austenitizing temperature and tempering.

Through the research cited above, it was possible to obtain some hypotheses of what factors may influence the process of hardening and tempering. However, all articles and dissertations previously cited were studies for steel bars, drawn steel wires, about the studies are very scarce. Besides that, the use of polymer quenching medium (from water polymer solution), replacing the traditional quenching in oil, is still very recent and few scientific studies on the subject are found.

Studies that address the application of statistics in the process of quenching and tempering of SAE 9254 steel wires are, however, relatively few in the literature, hence the present research.

The results of limit of tensile strength and hardness obtained in this step are used to setting of the oven inside which makes a second pilot sample, to confirm that the settings of the process were enough so that the product would achieve the mechanical specifications. This implies considerable operating routine analysis and waiting time, reducing the productivity of the process due to low income, since the oven remains inoperable until it is configured.

\section{Heat Treatment and Mechanical Properties}

Quenching is related to sudden cooling after heating steel to the austenitizing temperature and aims to obtain a microstructure that gives mechanical properties, such as hardness and tensile strength limit for specific applications that require this condition. During the cooling stage in quenching the temperature drop promotes structural changes that result in the emergence of internal tensions and so it is necessary the realization of tempering. The tempering involves a series of micro structural transformations that tend to thermodynamic equilibrium. It is, therefore, a thermally activated process and thus direct function of time and temperature. This process is performed in addition to quenching being particularly important in the manufacture of steel for springs. It consists of heating the quenched material between $250^{\circ} \mathrm{C}$ to $650^{\circ} \mathrm{C}$ for a certain time, to increase the ductility and elastic (CALLISTER, 2012).

In a test of tensile strength limit the body of proof shall be on the head of a testing machine that applies an effort which tends to lengthen it up to the break, being measures the deformation by means of a device called a strain gauge. The test is performed on a body of proof with standardized dimensions, so that the results obtained can be compared, reproduced and measured on the machine itself. Usually the test occurs until the break of the material (what ranks as destructive) and allows you to measure the resistance of the material and the deformation as a function of applied voltage. This variation is extremely useful for engineering, and is determined by the route of the stress-strain curve. Above a certain level of tension, the materials begin to deform plastically until the break, at which point you get the limit of tensile strength (CHIAVERINI, 2012).

Steel industries are very used the universal testing machine of traction and it is common for the units of force used are kilogram-force per square millimeter $\left(\mathrm{kgf} / \mathrm{mm}^{2}\right)$ or MegaPascal (MPa). The technical standards used for the execution of mechanical tests are elaborated by the ASTM (American Society for Testing and Materials).

According to Chiaverini (2012), the hardness is a measure of the resistance of a metal to penetration. The most common methods to determine the hardness of a metal are the Brinell, Vickers and Rockwell. In this project will only be used the method Brinell Hardness (BH).

The mechanical properties hardness and tensile strength limit are directly related. In general the higher the hardness, the greater the tensile strength and limit how often the hardness is proportional to the wear resistance and durability in steel, she is used as a measure of the resistance to abrasion (PAULA, 2013). 


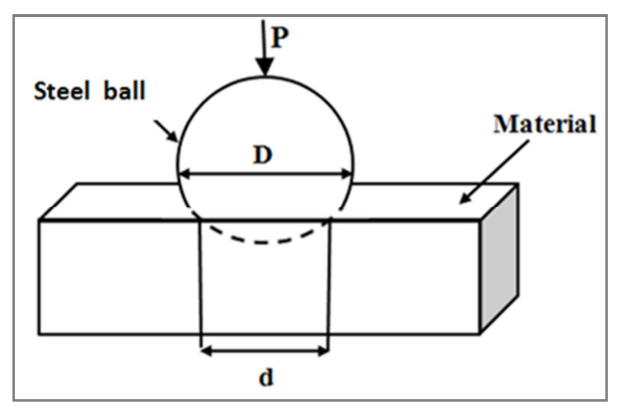

Figure 1. Illustration of the method of Brinell hardness $(B H)$.
Getting the values of Brinell Hardness (BH), as shown in Figure 1, is made by dividing the applied load by the area of penetration. The penetrator diameter (D) is a hardened steel ball to medium or low hardness materials, or tungsten carbide, for materials of high hardness. The test machine has a light microscope that makes measuring the diameter of the circle $(\mathrm{d}$, in $\mathrm{mm})$ that corresponds to the projection of the spherical Cap printed in the sample. Brinell hardness $(\mathrm{BH})$ will be given by the applied load $(\mathrm{P}$, in $\mathrm{kg}$ ) divided by the print area as (in formula 1):

$$
\text { Brinell hardness }=\frac{2 P}{\pi D\left(D-\sqrt{D^{2}}-d^{2}\right)}\left[\mathrm{kgf} / \mathrm{mm}^{2}\right]
$$

\section{Statistical Methods and Optimization}

Response surface methodology is based on the empirical mathematical models construction usually uses quadratic polynomial functions to offer conditions optimization for systems. According to Silva (2013) the response surface Methodology or RSM is a statistical technique to model processes and optimize the response variables, seeking a maximum or a minimum of income on which to optimize. Typically, using a factorial planning $2^{2}$, investigating two factors, to research the region great, by the way of maximum or minimum rise, depending on what if you want to optimize and the method of least squares is used to estimate the parameters of the quadratic model (polynomial), used to find the best fit of the factors, which will provide achieve the best response variable.

According to Neto et al. (2007), response surface methodology (or RSM) is an optimization technique based on factorial planning and has been used with great success in the modeling of various types of industrial processes. Application of response surface Methodology is necessary two phases, modeling, and offset. That must be carried out so often if you do need to, until you obtain the optimal surface region investigated. This modeling is accomplished using linear or quadratic models adjustment, in which the responses are obtained through the execution of planning factorials. The offset is made through the path of maximum rise of inclination of a given model, which is the path on which the variable response varies, and may cause bending, which occurs when a particular answer is increased gradually until at some point, begins to suffer a fall, this is called point of curvature of the response.

Like most issues involving the response surface is unknown, the first procedure is to find an approximation to the true relationship between the response variable (y) and independent variables (factors) and usually uses a mathematical modelling by means of a regression polynomial (quadratic). The following is presented that polynomial regression model of second order (in formula 2):

$$
y=\beta_{0}+\sum_{i=1}^{k} \beta_{i} x_{i}+\sum_{i=1}^{k} \beta_{i i} x_{i}^{2}+\sum_{i=1}^{k-1} \sum_{j>i}^{k} \beta_{i j} x_{i} x_{j}+\varepsilon
$$

at where:

- $\beta_{0}$ represents the average response variable;

- $\sum_{i=1}^{k} \beta_{i} x_{i}$ represents the linear effect;

- $\sum_{i=1}^{k} \beta_{i i} x_{i}^{2}$ represents the quadratic effect;

- $\sum_{i=1}^{k-1} \sum_{i>i}^{k} \beta_{i j} x_{i} x_{i}+\varepsilon$ represents the effect of the interaction.

As Rosa et al. (2009) and belt and Correia (2011), to analyze statistically the results obtained through design of experiments and response surface Methodology (RSM), the most recommended method is the analysis of variance (ANOVA), by means of which, you can compare two or more factors and also test the significance of the regression, making use of the F-test to establish which factors and interactions between them are really significant in the process as well as testing the significance of the curvature. From the parameters calculated on ANOVA can create eou validate statistical models, as well as calculate the coefficients necessary for process modeling through multiple regression can be linear, quadratic or interaction terms.

The Generalized Reduced Gradient method (GRG) has its structure based on an algorithm for solving nonlinear programming problems with constraints. Basically, the method provides only the use of linear or non-linear constraints of equality. However, for situations where the constraints are inequalities, solves the problem by introducing slack variables (if the constraint is of type $\leq$ ), or excess variables (in the case of restrictions of the type $\geq$ ).

The GRG is an algorithm applied to optimization problems and was developed by Leon Lasdon, University of Texas at Austin, and Allan Waren, Cleveland State University. For optimization through the Generalized Reduced Gradient Algorithm (GRG), you can use Microsoft Excel Solver, which is used for optimizing nonlinear problems, through this method (SACOMAN, 2012). Microsoft Excel Solver uses iterative numerical methods involving assessment values 
for the adjustable cells and observes the results calculated by cells of restrictions. Each attempt is called an interaction. Because in a trial-and-error approach would require an extremely long time (especially for problems involving several adjustable cells and constraints). However, the Microsoft Excel Solver performs comprehensive analysis of observed results and change fees as are varied to guide the selection of new evaluation values.

The Genetic Algorithms (GA) have a wide application in many scientific areas, among which may be mentioned problems solutions optimization, machine learning, developing strategies and mathematical formulas, analysis of economic models, engineering problems, diverse applications in biology as simulation of bacteria, immune systems, ecosystems, discovery of format and properties of organic molecules (ZINI, 2009).

According to Holland (1975), the fittest individuals have a greater number of descendants, unlike those individuals least able. The requirements for the implementation are:

a) Representations of possible solutions of the problem in the form of a genetic code;

b) Initial population containing diverse enough to allow the algorithm to combine features and produce new solutions;

c) Existence of a method to measure the quality of a potential solution;

d) combination of solutions to generate new individuals in the population;

e) A choice of solutions that will remain in the population or it will be removed;

f) A procedure to introduce periodically changes to some solutions. In this way the diversity of the population and the possibility to produce innovative solutions to be evaluated on criteria of selection of the fittest.

The basic principle of genetic operators is to transform the population through successive generations, extending the search to reach a satisfactory result. Genetic operators are necessary for the population if diversify and keep the adaptation features acquired by previous generations. Through the crossing are created new individuals, mixing characteristics of two parents. This mixture is done trying to imitate the reproduction of genes into cells and the result of this operation is an individual that potentially combine the best features of individuals used as base (HOLLAND, 1975).

According to Silva (2013), the Meta-heuristics are advanced methods that manage interactions between local refinement procedures and high-level strategies to create a process able to escape from great local situations, and provide a search optimal solutions.

Its origin is related to the adjustment of mechanical properties through a controlled cooling process, in which the product is heated to a certain temperature and then cooled in cooling, according to the desired result. If the goal is to obtain hardness and rigidity, the temperature is decreased abruptly. If, on the contrary, we want flexibility, the reduction is made slowly, until the ambient temperature (JUNIOR, 2008).

According to Barros and Moccellin (2004), the use of Simulated Annealing is justified by the ability to perform movements "up the Hill" in the space of feasible solutions of the problem, exploring the "valleys" in an attempt to obtain a global optimal solution to the problem. The Simulated Annealing can be considered a generalization of the method "descendant", in which the search is extended to a global minimum is completed after a local minimum be obtained, and may be classified as heuristic random search method in the neighborhood.

According to Yamamoto (2004), an important feature of Simulated Annealing is the acceptance of settings that have a higher energy, which can look worse, but allows the method does not converge to a local minimum, and could converge to a better result.

\section{Results}

\subsection{Material and Selection of Factors}

The material used in this study was the SAE 9254 cold drawn steel, used for the manufacture of Springs valves and clutch Springs applied to the automotive segment, with diameters $2.00 \mathrm{~mm}$ and $6.50 \mathrm{~mm}$, subjected to the process of hardening and tempering.

The chemical analysis of the SAE 9254 material used in the study is presented in table 1 .

Table 1. Chemical Composition (SAE 9254).

\begin{tabular}{llllllllllll}
\hline Chemical Elements & $\mathbf{C}$ & Mn & Si & P & S & Cr & Ni & Mo & Cu & Al & V \\
\hline (percentage) & 0.554 & 0.64 & 1.22 & 0.022 & 0.018 & 0.58 & 0.04 & 0.03 & 0.01 & 0.009 & 0.005 \\
\hline
\end{tabular}

The factors investigated were:

a) Speed of passage of wire inside the oven (in meters per second)- Factor A;

b) Lead in tempering temperature $\left(\right.$ in $\left.^{\circ} \mathrm{C}\right)$ - Factor $\mathrm{B}$;

The factor $\mathrm{A}$ and $\mathrm{B}$ were experienced by means of factorial planning, using the array called $2^{2}$ with center point and the star experiment values that will be used for quadratic modeling (in table 2 and formula 3 ) and the values were transformed to standardized variables. To conduct the experiments planning, standardized variables were used $(\beta)$ rather than physical variables (real adjustments) of the investigated factors in order to protect sensitive data from funding research firm. The standardization of the variables was calculated using the physical value $(\alpha)$ that want to test subtracted from the mean $(\mu)$ between the minimum and maximum values of settings of factors. The result divided by half the amplitude $(\mathrm{R})$ between the minimum and maximum values of settings of factors. Thus, the dimensionality of the standardized variables was restricted to the interval $[-1,1]$, which concentrates the minimum, average and maximum 
values. To values that will be used for quadratic modelling

was used -1.41 and 1.41 (to star experiment).

Table 2. Physical variables and standardized variables (multiple responses).

\begin{tabular}{lll}
\hline Input variables & Values (physical units) & Values (standardized variables) \\
\hline Speed (meters per second) & Minimum Star / Minimum / Center point/ Maximum/ Maximum Star & $-1.41 /-1 / 0 / 1 / 1.41$ \\
Lead temperature $\left({ }^{\circ} \mathrm{C}\right)$ & Minimum Star / Minimum / Center point / Maximum/ Maximum Star & $-1.41 /-1 / 0 / 1 / 1.41$ \\
\hline
\end{tabular}

$$
\beta=\frac{\alpha-\mu}{\frac{R}{2}}
$$

response variable tensile strength limit to the diameter of $2.00 \mathrm{~mm}$, was called Star experiment, which refers to a sequence of planned experiments in the region which is the curvature, seeking a quadratic modeling of the process. The star, was studied only the two main factors (A and B) as together, explain most of the influence generated in response limit of tensile strength. The result of the experiment and the results obtained after execution of the experiments are presented in table 3 .

\subsubsection{Response Surfaces for the Limit of Tensile Strength (2.00 Mm)}

First of all, to analyze the response surface, only the

Table 3. Experimental Matrix quadratic modelling of limit of tensile strength (MPa).

\begin{tabular}{llllllll}
\hline SPEED (A) & TEMPERATURE (B) & \multicolumn{1}{l}{ TENSILE STRENGTH -REPLICAS } \\
\hline-1 & -1 & 2149 & 2146 & 2148 & 2161 & 2167 & 2160 \\
1 & -1 & 2157 & 2157 & 2155 & 2151 & 2157 & 2157 \\
-1 & 1 & 1924 & 1920 & 1922 & 1921 & 1920 & 1918 \\
1 & 1 & 1924 & 1922 & 1924 & 1943 & 1945 & 1945 \\
-1.41 & 0 & 1700 & 1750 & 1750 & 1750 & 1700 & 1730 \\
1.41 & 0 & 1600 & 1600 & 1600 & 1600 & 1580 & 1600 \\
0 & -1.41 & 2010 & 2010 & 2010 & 2010 & 2012 & 2010 \\
0 & 1.41 & 1680 & 1700 & 1700 & 1700 & 1680 & 1700 \\
0 & 0 & 2046 & 2040 & 2041 & 2049 & 2047 & 2053 \\
\hline
\end{tabular}

After completion of the experiments with the purpose of quadratic modeling was carried out a new test of significance (using Tstudent statistic). Through of this test (in table 4), it was found that the factors (A) and (B) are influential, as well as the quadratic terms of $\mathrm{A}$ and $\mathrm{B}$. However, quadratic modelling, it was observed that the interaction term was not considered influential under the conditions tested.

Table 4. Test of significance for quadratic modeling (limit of tensile strength - Diameter $2.00 \mathrm{~mm}$ ).

\begin{tabular}{llll}
\hline Terms & Coefficient & $\mathbf{T}$ & $\mathbf{p}$ \\
\hline Constant & 2046.0 & 131.048 & 0.000 \\
$(\mathrm{~A})$ & 14.18 & 2.569 & 0.013 \\
$(\mathrm{~B})$ & -145.91 & -26.433 & 0.000 \\
$(\mathrm{~A})(\mathrm{A})$ & -45.21 & -4.939 & 0.000 \\
$(\mathrm{~B})(\mathrm{B})$ & 42.17 & 4.607 & 0.000 \\
$(\mathrm{~A})(\mathrm{B})$ & 3.13 & 0.400 & 0.691 \\
\hline
\end{tabular}

For a better understanding of the tensile strength limit, was built the 3D graph (in Figure 2) showing the behavior of the response surface in relation to adjustments of the factors. Looking at Figure 2, you can see that the reduction factor adjustment (B) from level 1 to -1 , it causes increase in tensile strength limit. The same occur with factor (A) from -1 to zero $(0)$, increasing the same property. When increased up to overcome the zero point (0), it was observed that the mechanical property suffers fall, indicating that the speed above the point zero (0) causes the processing time who is insufficient to cause the hardening and tempering in material, making it impossible for the micro structural transformation.

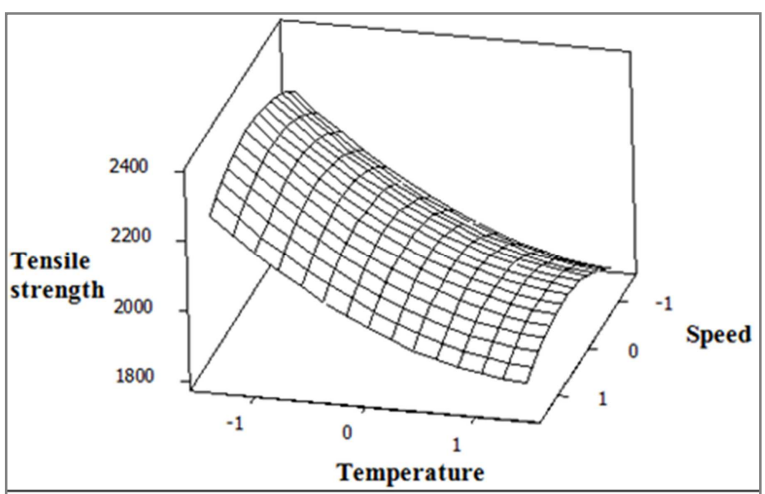

Figure 2. Response surface of - Diameter $2.00 \mathrm{~mm}(\mathrm{MPa})$.

\subsubsection{Response Surfaces for Hardness (Diameter $2.00 \mathrm{~mm}$ )}

It was made the star experiment in the region which is the curvature for mechanical property hardness, seeking a quadratic modeling of the process. For the star experiment (in table 5), has also been studied only the two main factors (A and $\mathrm{B})$. 
Table 5. Experimental Matrix quadratic model of the limit of Hardness - Diameter 2.00mm (BH).

\begin{tabular}{llllllll}
\hline SPEED (A) & TEMPERATURE (B) & HARDNESS - REPLICAS & & & \\
\hline-1 & -1 & 608 & 606 & 606 & 611 & 611 & \\
1 & -1 & 608 & 608 & 608 & 608 & 608 & 608 \\
-1 & 1 & 544 & 542 & 542 & 542 & 542 & 542 \\
1 & 1 & 544 & 544 & 542 & 550 & 550 & 550 \\
-1.41 & 0 & 530 & 532 & 533 & 533 & 537 & 530 \\
1.41 & 0 & 550 & 553 & 554 & 548 & 551 & 556 \\
0 & -1.41 & 630 & 628 & 627 & 628 & 633 & 638 \\
0 & 1.41 & 517 & 520 & 516 & 520 & 522 & 519 \\
0 & 0 & 578 & 575 & 578 & 578 & 578 & 581 \\
\hline
\end{tabular}

Through the test of significance (using statistics Tstudent), presented in table 6 , it was found that the factors (A) and (B) are influential, as well as the quadratic term, with $\mathrm{P}$ values less than 0.05 (for reliable 95). However, it was observed that the term $\mathrm{B}^{2}$ and interaction do not have significant influence.

Table 6. Significance test for hardness quadratic modelling - Diameter 2.00 $m m(B H)$.

\begin{tabular}{llll}
\hline Terms & Coefficient & T & p \\
\hline Constant & 578,0 & 135.067 & 0.000 \\
(A) & 3,885 & 2.568 & 0.013 \\
(B) & -35.719 & -23.608 & 0.000 \\
(A)(A) & -13.396 & -5.339 & 0.000 \\
(B)(B) & 2.896 & 1.154 & 0.254 \\
(A)(B) & 1.292 & 0.604 & 0.549 \\
\hline
\end{tabular}

Looking at Figure 3, you can see that the reduction factor (B) from level 1 to -1 causes increase in hardness. It was observed that the increase in factor (A) from level -1 to zero causes an increase in hardness. However, the hardness had a crash, when the increase was above the zero point, because the processing time was insufficient to tempering in the material, making it impossible for the micro structure transformation. With that, it was found the maximum speed permitted for obtaining the greatest result of hardness.

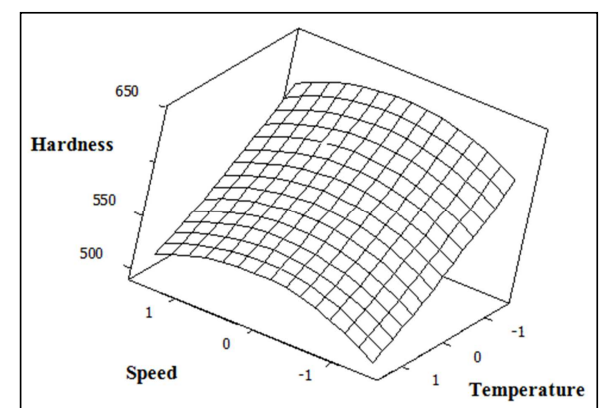

Figure 3. Response surface hardness- Diameter $2.00 \mathrm{~mm}$ (BH).4.3. Application of Response Surface Methodology (Diameter $6.50 \mathrm{~mm}$ )

\subsubsection{Response Surfaces for Limit of Tensile Strength $(6.50 \mathrm{~mm})$}

To analyze the response surface, only the response variable tensile strength limit, to $6.50 \mathrm{~mm}$ diameter, it was made the star experiment. The star experiment, have also been studied only the two main factors (A and B) because together, explain most of the influence generated in response. The results obtained after execution of the experiments are shown in table 7.

Table 7. Experimental Matrix quadratic model of the limit of tensile strength-Diameter $6.50 \mathrm{~mm}(\mathrm{MPa})$.

\begin{tabular}{|c|c|c|c|c|c|c|c|}
\hline \multirow{2}{*}{$\begin{array}{l}\text { SPEED (A) } \\
-1\end{array}$} & \multirow{2}{*}{$\begin{array}{l}\text { TEMPERATURE (B) } \\
-1\end{array}$} & \multicolumn{6}{|c|}{ TENSILE STRENGTH -REPLICAS } \\
\hline & & 1968 & 1974 & 1962 & 1971 & 1971 & 1974 \\
\hline 1 & -1 & 1980 & 1976 & 1988 & 1978 & 1980 & 1988 \\
\hline-1 & 1 & 1771 & 1764 & 1763 & 1773 & 1771 & 1764 \\
\hline 1 & 1 & 1796 & 1784 & 1797 & 1781 & 1796 & 1784 \\
\hline-1.41 & 0 & 1700 & 1750 & 1750 & 1750 & 1700 & 1730 \\
\hline 1.41 & 0 & 1600 & 1600 & 1600 & 1600 & 1580 & 1600 \\
\hline 0 & -1.41 & 2010 & 2010 & 2010 & 2010 & 2012 & 2010 \\
\hline 0 & 1.41 & 1680 & 1700 & 1700 & 1700 & 1680 & 1700 \\
\hline 0 & 0 & 1850 & 1847 & 1849 & 1848 & 1844 & 1846 \\
\hline
\end{tabular}

Table 8. Test of significance of the quadratic model of the limit of tensile strength-Diameter $6.50 \mathrm{~mm}(\mathrm{MPa})$.

\begin{tabular}{llll}
\hline Terms & Coefficient & T & p \\
\hline Constant & 1847.33 & 67.523 & 0.000 \\
(A) & -19.36 & -2.002 & 0.050 \\
(B) & -105.33 & -10.889 & 0.000 \\
(A)(A) & -62.08 & -3.870 & 0.000 \\
(B)(B) & 32.17 & 2.005 & 0.050 \\
(A)(B) & 2.58 & 0.189 & 0.851 \\
\hline
\end{tabular}

After the completion of the experiments with the purpose of quadratic modeling was performed significance testing (in table 8), which made possible to complete that the factors (A) and (B) are influential, as well as the quadratic terms of $A$ and $\mathrm{B}$, with $\mathrm{P}$ values of (0.05) of significance. However, for the quadratic modeling, it was observed that the interaction was not influential.

For better understanding of the response surface of $6.50 \mathrm{~mm}$ diameter, for the mechanical property limit of tensile strength, it was built the 3D graph (in Figure 4), showing the behavior of the response in relation to adjustments of the factors. 


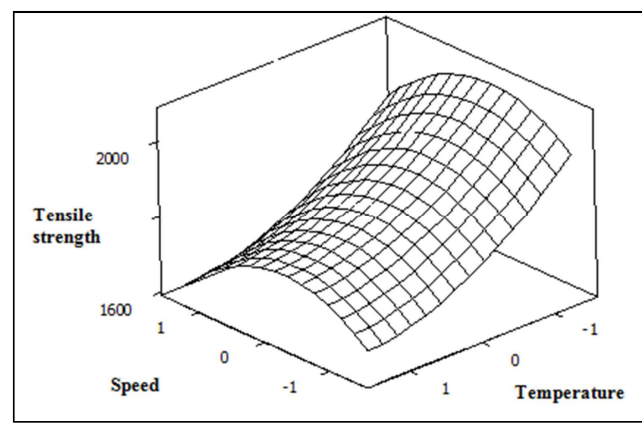

Figure 4. Response surface of tensile strength-Diameter $6.50 \mathrm{~mm}(\mathrm{MPa})$.

Analyzing the Figure 4, it was possible to observe that the reduction factor (B) from 1 to -1 causes increase in tensile strength limit. On the other hand, the influence of the factor (A) it was significant when increased from -1 to zero (0), which was reflected in the increase in the tensile strength limit because with the increased above the point called curvature (zero), it was observed that the mechanical property crash, indicating that the speed above the zero point cause an insufficient processing time for the modification structural.

\subsubsection{Response Surfaces for Hardness (Diameter $6.50 \mathrm{~mm}$ )}

For mechanical property hardness in diameter $6.50 \mathrm{~mm}$, it was made the star experiment, in the region which is the curvature. For the star experiment (in table 9), was studied only the two main factors (A and B).

Table 9. Experimental Matrix quadratic modelling of hardness-Diameter $6.50 \mathrm{~mm}(\mathrm{BH})$.

\begin{tabular}{llllllll}
\hline SPEED (A) & TEMPERATURE (B) & \multicolumn{7}{l}{ HARDNESS -REPLICAS } & & \\
\hline-1 & -1 & 556 & 558 & 556 & 556 & 556 & 558 \\
1 & -1 & 558 & 558 & 561 & 558 & 558 & 561 \\
-1 & 1 & 500 & 497 & 497 & 500 & 500 & 497 \\
1 & 1 & 508 & 503 & 508 & 503 & 508 & 503 \\
-1.41 & 0 & 480 & 482 & 480 & 485 & 490 & 484 \\
1.41 & 0 & 400 & 400 & 410 & 405 & 400 & 400 \\
0 & -1.41 & 580 & 590 & 590 & 580 & 580 & 582 \\
0 & 1.41 & 410 & 410 & 413 & 400 & 410 & 400 \\
0 & 0 & 522 & 522 & 522 & 522 & 519 & 522 \\
\hline
\end{tabular}

After the completion of the experiments with the purpose of quadratic modeling was performed significance testing (in table 10) which made possible to complete that the factors (A) and (B) are influential, as well as the quadratic terms of $A$ and $B$, with $P$ values of (0.05) of significance. However, for the quadratic modeling, it was observed that the quadratic term of $\mathrm{B}$ and the interaction does not have significant influence on this response variable.

Table 10. Test of significance for quadratic modeling-Diameter $6.50 \mathrm{~mm}$ hardness (HB).

\begin{tabular}{llll}
\hline Terms & Coefficient & T & p \\
\hline Constant & 521.500 & 33.325 & 0.000 \\
(A) & -13.152 & -2.377 & 0.021 \\
(B) & -45.159 & -8.162 & 0.000 \\
(A)(A) & -24.073 & -2.624 & 0.012 \\
(B)(B) & 2.135 & 0.233 & 0.817 \\
(A)(B) & 1.167 & 0.149 & 0.882 \\
\hline
\end{tabular}

For better understanding of the response surface, mechanical property hardness, it was presented the 3D graph (in Figure 5), showing the behavior of the response in relation to adjustments of the factors.

Looking at Figure 5, you can see that the reduction factor (B) from 1 to -1 causes increase in tensile strength limit. However, increasing the factor (A) from -1 to zero, consequently will cause increasing hardness. However, it was observed that the mechanical property suffered crash when the speed has been increased above the point of curvature zero, indicating that the speed above the zero point cause an insufficient processing time for the modification structural.

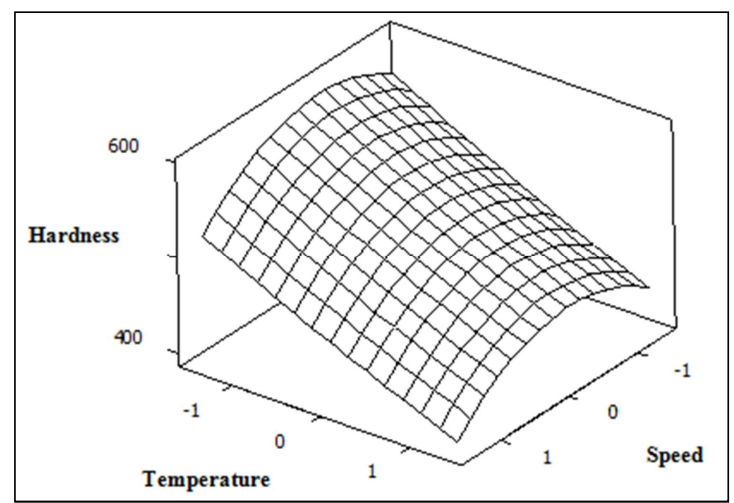

Figure 5. Response surface hardness-Diameter $6.50 \mathrm{~mm}(\mathrm{BH})$.

Using the coefficients for the diameter $2.00 \mathrm{~mm}$ was possible to create quadratic models that represent the process, referring to limit tensile strength and hardness (in Formulas 4 and 5):

$$
\begin{aligned}
\text { Tensile strength } & =2046+14.18(\mathrm{~A})-145.91(\mathrm{~B})-45.21\left(\mathrm{~A}^{2}\right)+42.17\left(\mathrm{~B}^{2}\right) \\
\text { hardness } & =578+3.885(\mathrm{~A})-35.719(\mathrm{~B})-13.396\left(\mathrm{~A}^{2}\right)
\end{aligned}
$$

Afterwards, will be presented the quadratic modeling for $6.50 \mathrm{~mm}$ diameter (in Formulas in 6 and 7):

$$
\text { Tensile strength }=1847.33-19.36(\mathrm{~A})-105.33(\mathrm{~B})-62.08\left(\mathrm{~A}^{2}\right)+32.17\left(\mathrm{~B}^{2}\right)
$$




$$
\text { hardness }=521.500-13.152(\mathrm{~A})-45.159(\mathrm{~B})-24.073\left(\mathrm{~A}^{2}\right)
$$

\section{Optimization of the Quadratic Model}

To the optimization of the process through the application of methods Generalized Reduced Gradient (GRG), Genetic Algorithm (GA) and the Meta-heuristics Simulated Annealing. For this we used the Solver tool contained in Excel software; CrystalBall Software and the Scilab Software. In this step, the optimization will occur for the two diameters studied (simultaneously), optimizing the results for three customers of this product. That way, you can test the model Quadratic optimizing for three different methods in different situations by checking the error level obtained in each method.

In Table 11 in the programming Worksheet are all informations necessaries for the development and application of optimization methods. As well as the specifications listed in assigned to mathematical models, levels of factors, predictions generated by the model and results achieved for each mechanical property and diameter.

Table 11. Worksheet for application of the optimization methods.

\begin{tabular}{|c|c|c|c|c|c|c|c|}
\hline & $\mathbf{A}$ & B & C & D & $\mathbf{E}$ & $\mathbf{F}$ & $\mathbf{G}$ \\
\hline 1 & & Constant & $\mathrm{A}$ & B & $\mathrm{A}^{2}$ & $\mathrm{~B}^{2}$ & Error Tensile strength (\%)-2.00mm \\
\hline 2 & & 2046 & 14.18 & -145.91 & -45.21 & 42.17 & $=\left(\mathrm{C}_{4}-\mathrm{C}_{7}\right) * 100 / \mathrm{C}_{7}$ \\
\hline 3 & Tensile strength & Adjustment Factor & & & & & \\
\hline 4 & Diameter $2.00 \mathrm{~mm}$ & Prediction Model & & & & & Average error $(\%)-2.00 \mathrm{~mm}$ \\
\hline 5 & & Objective Function & $=\mathrm{G} 5$ & & & & $=$ Average $\left(\mathrm{G}_{2} ; \mathrm{N}_{9}\right)$ \\
\hline 6 & & Factor specification & -1 & 1 & & & \\
\hline \multirow[t]{2}{*}{7} & Specification of Mechanical Property & 1930 (Minimum) & \multicolumn{2}{|c|}{2040 (Target) } & \multicolumn{2}{|c|}{2150 (Maximum) } & \\
\hline & $\mathrm{H}$ & I & $\mathrm{J}$ & $\mathrm{K}$ & $\mathrm{L}$ & M & $\mathrm{N}$ \\
\hline 8 & & Constant & A & B & $\mathrm{A}^{2}$ & $\mathrm{~B}^{2}$ & Error Hardness (\%)-2.00mm \\
\hline 9 & & 578 & 3885 & -35719 & -13396 & - & $=\left(\mathrm{J}_{11}-\mathrm{J}_{13}\right)^{*} 100 / \mathrm{J}_{13}$ \\
\hline 10 & Hardness & Adjustment Factor & & & & & \\
\hline 11 & Diameter $2.00 \mathrm{~mm}$ & Prediction Model & & & & & \\
\hline 12 & & Factor specification & -1 & 1 & & & \\
\hline \multirow[t]{2}{*}{13} & Specification of Mechanical Property & 545 (Minimum) & \multicolumn{2}{|c|}{572 (Target) } & \multicolumn{2}{|c|}{600 (Maximum) } & \\
\hline & $\mathrm{O}$ & $\mathrm{P}$ & Q & $\mathrm{R}$ & $\mathrm{S}$ & $\mathrm{T}$ & $\mathrm{U}$ \\
\hline 14 & & Constant & A & B & $\mathrm{A}^{2}$ & $\mathrm{~B}^{2}$ & Error Tensile strength (\%)-6.50mm \\
\hline 15 & & 1847.33 & -19.36 & -105.33 & -62.08 & 32.17 & $=\left(\mathrm{Q}_{17}-\mathrm{Q}_{20}\right)^{*} 100 / \mathrm{Q}_{20}$ \\
\hline 16 & Tensile strength & Adjustment Factor & & & & & \\
\hline 17 & Diameter $6.50 \mathrm{~mm}$ & Prediction Model & & & & & Average error $(\%)-6.50 \mathrm{~mm}$ \\
\hline 18 & & Objective Function & $=\mathrm{U} 18$ & & & & $=$ Average $\left(\mathrm{U}_{15} ; \beta_{22}\right)$ \\
\hline 19 & & Factor specification & -1 & 1 & & & \\
\hline \multirow[t]{2}{*}{20} & Specification of Mechanical Property & 1770 (Minimum) & \multicolumn{2}{|c|}{1875 (Target) } & \multicolumn{2}{|c|}{1980 (Maximum) } & \\
\hline & $\mathrm{V}$ & $\mathrm{W}$ & $\mathrm{X}$ & $\mathrm{Y}$ & $\mathrm{Z}$ & $\alpha$ & $\beta$ \\
\hline 21 & & Constant & A & B & $\mathrm{A}^{2}$ & $\mathrm{~B}^{2}$ & Error Hardness (\%)-6.50mm \\
\hline 22 & & 521.5 & -13152 & -45159 & -24073 & - & $=\left(\mathrm{X}_{24}-\mathrm{X}_{26}\right)^{*} 100 / \mathrm{X}_{26}$ \\
\hline 23 & Hardness & Adjustment Factor & & & & & \\
\hline 24 & Diameter $6.50 \mathrm{~mm}$ & Prediction Model & & & & & \\
\hline 25 & & Factor specification & -1 & 1 & & & \\
\hline 26 & Specification of Mechanical Property & 500 (Minimum) & $530(\mathrm{Ta}$ & & $560\left(\mathrm{M}_{\mathrm{c}}\right.$ & mum) & \\
\hline
\end{tabular}

\subsection{Optimization by Generalized Reduced Gradient (GRG)-Quadratic Model}

For the application of this method was necessary for the definition of:

a) Specifications: specifications (in Table 11) concerning the response variable tensile strength limit, $2.00 \mathrm{~mm}$ diameter, will be located in cells $\mathrm{B}_{7}, \mathrm{C}_{7}$ and $\mathrm{E}_{7}$. While for $6.50 \mathrm{~mm}$ diameter are in cells $\mathrm{P}_{20}, \mathrm{Q}_{20}$ and $\mathrm{S}_{20}$. To the specifications relating to the response variable hardness, diameter $2.00 \mathrm{~mm}$, Non cells, $\mathrm{J}_{13}$ and $\mathrm{L}_{13}$. While for $6.50 \mathrm{~mm}$ diameter are in cells, $\mathrm{W}_{26} \mathrm{X}_{26}$ and $Z_{26}$. However, these cells are only the locations of data placement, varying specifications of three customers, as they are being simulated situations.

b) Decision variables: in this case, refers to the values of the settings, and $\mathrm{B}$, to be afforded the best condition of meeting the specifications of the mechanical responses. In this case the corresponding cells are: response variable tensile strength limit, $2.00 \mathrm{~mm}$ diameter (cells 
$\mathrm{C}_{3}$ and $\mathrm{D}_{3}$ ); response variable tensile strength limit, 6.50 $\mathrm{mm}$ diameter (cells $\mathrm{Q}_{16}$ and $\mathrm{R}_{16}$ ); response variable hardness, diameter $2.00 \mathrm{~mm}$ (cells $\mathrm{J}_{10}$ and $\mathrm{K}_{10}$ ); response variable hardness, diameter $6.50 \mathrm{~mm}$ (cells $\mathrm{X}_{23}$ and $\left.\mathrm{Y}_{23}\right)$;

c) Restrictions: some restrictions (in Table 11) were charged in solver, such as, the values of the factors $A$ and $\mathrm{B}$ (cells $\mathrm{C}_{3}$ and $\mathrm{D}_{3}, \mathrm{~J}_{10}$ and $\mathrm{K}_{10}, \mathrm{Q}_{16}$ and $\mathrm{R}_{16}, \mathrm{X}_{23}$ and $\mathrm{Y}_{23}$ ) were restricted to a minimum and a maximum of -1 to 1 (corresponding to the reduced variable study). While the values of model predictions (cells: $\mathrm{C}_{4}, \mathrm{~J}_{11}$, $\mathrm{Q}_{17}$ and $\mathrm{X}_{24}$ ) were restricted to your specifications, in relation to the mechanical property and the diameter

d) Objective function: the objective function was used To the distance Average Percentage, which is the average distance of the predictions of responses, that is, for each response predicted by the model subtracts the value "target"; so if it gets a error unit between the prediction and the nominal specification, which shall be multiplied by one hundred, for use in percentage. In this case, the objective function is the minimisation of the average of those "errors", seeking a condition that reduces to the maximum values of the distances simultaneously of two variables simultaneously for a given diameter answers, seeking a balance between the best fit of the answers. The objective function for the diameter $2.00 \mathrm{~mm}$ appear in cell $\mathrm{C}_{5}$ and for the diameter $6.50 \mathrm{~mm}$ in cell $\mathrm{Q}_{18}$ (in Table 11).

With the use of Solver tool contained in Excel software (2010 version). It was possible to allocate all the information previously mentioned. In this way, one can obtain the results of optimization that will be analyzed later.

\subsection{Optimization by Genetic Algorithm (GA)-Quadratic Model}

The application of the Genetic Algorithm method (AG) to quadratic modelling similarly to optimization by (GRG) held previously, it was also used in Table 11 and followed the same steps for use of specifications, decision variables and constraints and objective function. The data were imputed in CrystalBall software which is a complementary Software to Excel software (version 2010) and owns the resource optimization by Genetic Algorithm (GA). Five thousand simulations were performed in each desired condition and analysis concerning the optimization by Genetic Algorithms (AG) will be held later.

\subsection{Optimization by Simulated Annealing-Quadratic Model}

For optimization of the quadratic models was used the Meta-heuristics Simulated Annealing in order to find the best fit possible for optimization factors of multiple mechanical responses (limit of tensile strength and hardness).

The Simulated Annealing method was applied using Scilab software Enterprises (for numerical computation), as shown in table 12 .

The simulations using Simulated Annealing were performed primarily for the diameter $2.00 \mathrm{~mm}$ in which were held 2245 simulations until it was achieved the best condition for obtaining adjustments of responses (in table 12). The simulations are presented in summary form and $\mathrm{y}_{1}$ and $\mathrm{y}_{2}$ values of mechanical properties tensile strength limit and hardness being A (Speed factor) and B (lead temperature factor).

Table 12. Simulated Annealing (Scilab), diameter $2.00 \mathrm{~mm}$ - quadratic Modeling (example application).

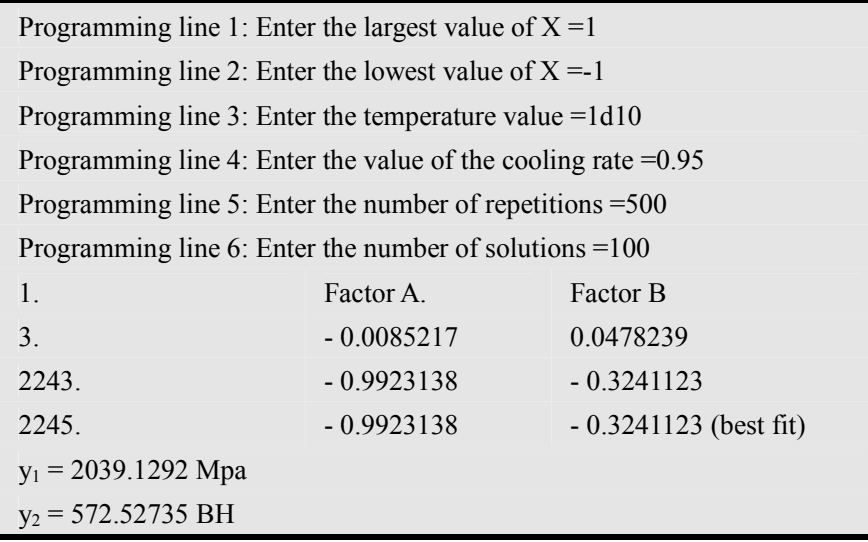

The same procedure was performed for the simulations for the diameter $6.50 \mathrm{~mm}$ in (in table 13). 2245 simulations were carried out also until it was achieved the best condition of adjustments to obtain the mechanical responses variables $\left(\mathrm{y}_{1}\right.$ and $\left.\mathrm{y}_{2}\right)$.

Table 13. Simulated Annealing (Scilab), diameter $6.50 \mathrm{~mm}$ - quadratic Modeling (example application).

Programming line 1: Enter the largest value of $\mathrm{X}=1$
Programming line 2: Enter the lowest value of $\mathrm{X}=-1$
Programming line 3: Enter the temperature value $=1 \mathrm{~d} 10$
Programming line 4: Enter the value of the cooling rate $=0.95$
Programming line 5: Enter the number of repetitions $=500$
Programming line 6: Enter the number of solutions $=100$
$\begin{array}{lll}1 . & \text { Factor A } & \text { Factor B } \\ 3 . & -0.0819624 & 0.0250652 \\ 2243 . & 0.3870487 & -0.3803127 \\ 2245 . & 0.3870487 & -0.3803127 \text { (best fit) } \\ \mathrm{y}_{1}=1875.2367 & & \\ \mathrm{y}_{2}=529.97938 & & \end{array}$

\subsection{Evaluation of Optimization Methods - Quadratic Modeling}

After verification of the results obtained by optimization of mechanical responses variables by means of Generalized Reduced Gradient methods (GRG), Genetic Algorithm (GA) and Simulated Annealing it will be performed simulations for the three major customers of this product, for the verification of the power of optimization of multiple responses through these methods. In Table 14 are the specifications of the customers of this product (referring to the limit of tensile strength and hardness), for diameter $2.00 \mathrm{~mm}$. They were also assigned values to each customer target and achieved in each method optimization. 
Table 14. Comparison of results of the methods of optimization (diameter $2.00 \mathrm{~mm}$ ).

\begin{tabular}{|c|c|c|c|c|c|c|}
\hline & Customers 1 & & Customers 2 & & Customers 3 & \\
\hline & $\begin{array}{l}\text { Tensile strength } \\
\text { (MPa) }\end{array}$ & $\begin{array}{l}\text { Hardness } \\
\text { (HB) }\end{array}$ & $\begin{array}{l}\text { Tensile } \\
\text { strength (MPa) }\end{array}$ & $\begin{array}{l}\text { Hardness } \\
\text { (HB) }\end{array}$ & $\begin{array}{l}\text { Tensile strength } \\
\text { (MPa) }\end{array}$ & $\begin{array}{l}\text { Hardness } \\
\text { (HB) }\end{array}$ \\
\hline $\begin{array}{l}\text { Prediction by Simulated Annealing- } \\
\text { (Scilab) }\end{array}$ & 2030 & 573 & 1970 & 555 & 2100 & 590 \\
\hline Prediction by GRG-(Solver) & 2028 & 572 & 1966 & 555 & 2100 & 587 \\
\hline Prediction by GA-(CrystalBall) & 2040 & 572 & 1970 & 585 & 2100 & 555 \\
\hline Minimum specification & 1930 & 545 & 1900 & 530 & 1900 & 500 \\
\hline Specification (target) & 2040 & 572 & 1975 & 555 & 2100 & 600 \\
\hline Adjust Factor A (Simulated Annealing) & -0.99 & & 0.11 & & 0.11 & \\
\hline Adjust Factor A (GRG) & 0.90 & & 1.00 & & 1.00 & \\
\hline Adjust Factor A (GA) & -1.00 & & 0.20 & & 0.12 & \\
\hline Adjust Factor B (Simulated Annealing) & -0.32 & & 0.65 & & -0.33 & \\
\hline Adjust Factor B (GRG) & -0.04 & & 0.38 & & -0.51 & \\
\hline Adjust Factor B (GA) & -0.33 & & 0.65 & & -0.33 & \\
\hline
\end{tabular}

Tabela 15. Comparison of Errors of optimization methods (diameter $2.00 \mathrm{~mm}$ ).

\begin{tabular}{|c|c|c|c|c|c|c|}
\hline & \multicolumn{2}{|l|}{ Customers 1} & \multicolumn{2}{|l|}{ Customers 2} & \multicolumn{2}{|l|}{ Customers 3} \\
\hline & $\begin{array}{l}\text { Tensile strength } \\
(\mathrm{MPa})\end{array}$ & $\begin{array}{l}\text { Hardness } \\
\text { (HB) }\end{array}$ & $\begin{array}{l}\text { Tensile strength } \\
\text { (MPa) }\end{array}$ & $\begin{array}{l}\text { Hardness } \\
\text { (HB) }\end{array}$ & $\begin{array}{l}\text { Tensile strength } \\
\text { (MPa) }\end{array}$ & Hardness (HB) \\
\hline $\begin{array}{l}\text { Error \% (Simulated Annealing)- } \\
\text { Scilab }\end{array}$ & $0.04 \%$ & $0.08 \%$ & $0.25 \%$ & $0.00 \%$ & $0.00 \%$ & $1.60 \%$ \\
\hline Error \% (GRG)- Solver & $0.59 \%$ & $0.00 \%$ & $0.46 \%$ & $0.00 \%$ & $0.00 \%$ & $2.17 \%$ \\
\hline Error \% (GA)-CrystalBall & $0.00 \%$ & $0.00 \%$ & $0.25 \%$ & $5.41 \%$ & $0.00 \%$ & $7.50 \%$ \\
\hline $\begin{array}{l}\text { Error Medium (\%) (Simulated } \\
\text { Annealing) }\end{array}$ & \multicolumn{2}{|l|}{$0.06 \%$} & \multicolumn{2}{|l|}{$0.125 \%$} & \multicolumn{2}{|l|}{$0.80 \%$} \\
\hline Error Medium (\%) (GRG) & \multicolumn{2}{|l|}{$0.29 \%$} & \multicolumn{2}{|l|}{$0.23 \%$} & \multicolumn{2}{|l|}{$1.08 \%$} \\
\hline Error Medium (\%) (GA) & \multicolumn{2}{|c|}{$0.00 \%$} & \multicolumn{2}{|l|}{$2.83 \%$} & \multicolumn{2}{|l|}{$3.75 \%$} \\
\hline Error Medium (\%) of the three & \multicolumn{2}{|c|}{ (Simulated Annealing) } & \multicolumn{2}{|l|}{ (GRG) } & \multicolumn{2}{|l|}{ (GA) } \\
\hline customers & \multicolumn{2}{|c|}{$0.32 \%$} & $0.53 \%$ & & \multicolumn{2}{|l|}{$2.19 \%$} \\
\hline
\end{tabular}

Table 16. Comparison of results of the methods of optimization (diameter $6.50 \mathrm{~mm}$ ).

\begin{tabular}{|c|c|c|c|c|c|c|}
\hline & \multicolumn{2}{|l|}{ Customers 1} & \multicolumn{2}{|l|}{ Customers 2} & \multicolumn{2}{|l|}{ Customers 3} \\
\hline & $\begin{array}{l}\text { Tensile strength } \\
\text { (MPa) }\end{array}$ & $\begin{array}{l}\text { Hardness } \\
(\mathrm{HB})\end{array}$ & $\begin{array}{l}\text { Tensile } \\
\text { strength (MPa) }\end{array}$ & $\begin{array}{l}\text { Hardness } \\
(\mathrm{HB})\end{array}$ & $\begin{array}{l}\text { Tensile } \\
\text { strength (MPa) }\end{array}$ & $\begin{array}{l}\text { Hardness } \\
\text { (HB) }\end{array}$ \\
\hline Prediction by Simulated Annealing- (Scilab) & 1875 & 530 & 1763 & 490 & 1889 & 526 \\
\hline Prediction by GRG-(Solver) & 1875 & 530 & 1763 & 490 & 1857 & 525 \\
\hline Prediction by AG-(CrystalBall) & 1873 & 530 & 1760 & 490 & 1870 & 525 \\
\hline Minimum specification & 1770 & 500 & 1670 & 450 & 1800 & 510 \\
\hline Maximum specification & 1980 & 560 & 1850 & 530 & 1980 & 540 \\
\hline Specification (target) & 1875 & 530 & 1760 & 490 & 1890 & 525 \\
\hline Adjust Factor A (Simulated Annealing) & 0.38 & & -0.99 & & 0.99 & \\
\hline Adjust Factor A (GRG) & 0.38 & & -1.00 & & 0.13 & \\
\hline Adjust Factor A (GA) & -0.80 & & -0.87 & & -1.00 & \\
\hline Adjust Factor B (Simulated Annealing) & -0.38 & & 0.46 & & -0.91 & \\
\hline Adjust Factor B (GRG) & -0.37 & & 0.46 & & -0.13 & \\
\hline Adjust Factor B (GA) & -0.30 & & 0.55 & & -0.32 & \\
\hline
\end{tabular}

Table 17. Comparison of optimization methods (6.50 mm diameter).

\begin{tabular}{|c|c|c|c|c|c|c|}
\hline & \multicolumn{2}{|l|}{ Customers 1} & \multicolumn{2}{|l|}{ Customers 2} & \multicolumn{2}{|l|}{ Customers 3} \\
\hline & $\begin{array}{l}\text { Tensile } \\
\text { strength (MPa) }\end{array}$ & $\begin{array}{l}\text { Hardness } \\
\text { (HB) }\end{array}$ & $\begin{array}{l}\text { Tensile } \\
\text { strength (MPa) }\end{array}$ & $\begin{array}{l}\text { Hardness } \\
\text { (HB) }\end{array}$ & $\begin{array}{l}\text { Tensile } \\
\text { strength (MPa) }\end{array}$ & $\begin{array}{l}\text { Hardnes } \\
\text { s (HB) } \\
\end{array}$ \\
\hline Error \% (Simulated Annealing)- Scilab & $0.00 \%$ & $0.00 \%$ & $0.17 \%$ & $0.00 \%$ & $0.05 \%$ & $0.19 \%$ \\
\hline Error \% (GRG)- Solver & $0.00 \%$ & $0.00 \%$ & $0.17 \%$ & $0.00 \%$ & $1.75 \%$ & $0.00 \%$ \\
\hline Error \% (GA)-CrystalBall & $0.11 \%$ & $0.00 \%$ & $0.00 \%$ & $0.00 \%$ & $1.06 \%$ & $0.00 \%$ \\
\hline Error Medium (\%) (Simulated Annealing) & $0.00 \%$ & & $0.09 \%$ & & $0.12 \%$ & \\
\hline Error Medium (\%) (GRG) & $0.00 \%$ & & $0.09 \%$ & & $0.87 \%$ & \\
\hline Error Medium (\%) (GA) & $0.05 \%$ & & $0.00 \%$ & & $0.53 \%$ & \\
\hline \multirow{2}{*}{ Error Medium (\%)of the three customers } & \multirow{2}{*}{\multicolumn{2}{|c|}{$\begin{array}{l}\text { (Simulated Annealing) } \\
0.07 \%\end{array}$}} & (GRG) & & (GA) & \\
\hline & & & $0.32 \%$ & & $0.19 \%$ & \\
\hline
\end{tabular}




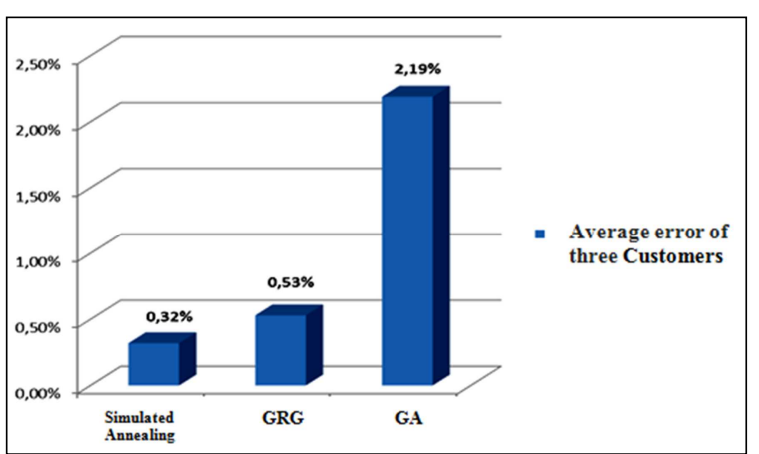

Figure 6. Comparison of optimization methods Errors (diameter $2.00 \mathrm{~mm}$ ).

You can see that the errors presented to the optimization of models regarding diameter $2.00 \mathrm{~mm}$ to all specifications of customers and through all optimization methods applied, were small and in any of them has reached the maximum value of 3 percent, which is considered a low index for this process (in Table 15). However, analyzing the average errors for each method of optimization in Figure 6, it can be concluded that the most effective method of optimization for the diameter $2.00 \mathrm{~mm}$ was the Simulated Annealing heuristic, which obtained an average error of 0.32 percent.

The same procedure of comparison of optimization methods was conducted to $6.50 \mathrm{~mm}$ diameter and the results were similar. In table 16 are presented the results of the simulations for the optimization of power check multiple responses through these methods.

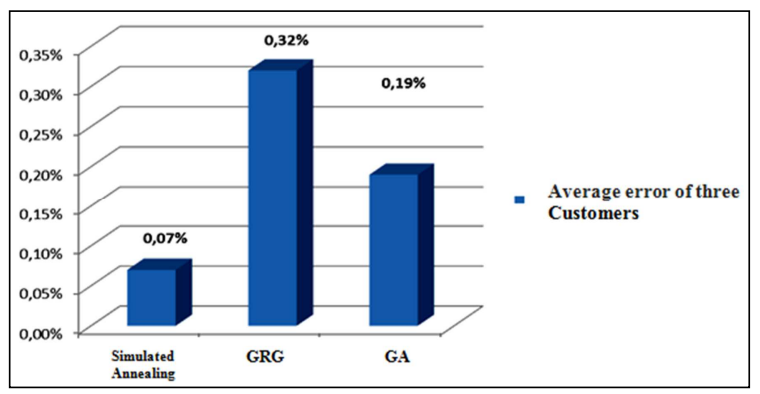

Figure 7. Comparison of optimization methods (diameter $6.50 \mathrm{~mm}$ ).

Analysing the results contained in the table 17 for optimization of models relating $6.50 \mathrm{~mm}$ diameter, it is found that the errors were still minors and in none of them this error reached the value of 1 between the target value and the value achieved showing the effectiveness of these methods of optimization for the quadratic modeling of this process. However, analyzing the average errors for each method of optimization (Figure 7), it can be concluded that the most effective method of optimization for the $6.50 \mathrm{~mm}$ diameter was the Simulated Annealing heuristic which we got error average of 0.07 percent.

\section{Conclusion}

It was concluded through experimental analyses all factors (speed, temperature and concentration of the polymer) are influential in the process of hardening and tempering in steel drawn wires SAE 9254 and that these factors interact with each other, significantly, being the lead temperature factor of greatest impact on increasing or reducing the mechanical values obtained.

It was observed that the best way of modeling this process is by quadratic modeling, by response surface Methodology because this provided a stable model and modelling able to obtain predictions ranging within specifications. As well as, understand that the best optimization for that modeling was by Meta-heuristics Simulated Annealing. However, the Generalized Reduced Gradient methods (GRG) and Genetic Algorithm (GA) achieved excellent results for the quadratic modeling and can also be used if necessary.

Taking into consideration that all methods tested for quadratic modeling optimization achieved good performance then the justification of the choice of Meta-heuristics Simulated Annealing was at the lowest average index error and also for ease of modification of the Scilab Software simulation programming because with only the change of the "line" regarding programming specifications a new simulation can be performed.

The implementation of this process modeling from simulations and the use of optimization methods studied can mean the automation of tempering furnaces, causing potential productivity gains, the reduction of waiting for laboratory results, less sampling for checks and shorter stops in furnaces.

It was concluded that the statistical and optimization methods studied in academic environment often employed only on a small scale in research laboratories in universities or in simulators they apply perfectly inside an industrial environment solving complex problems and being of great value for future innovations in industries.

Complete through the experience gained by the researcher who carried out this project, the experimental implementation in industrial environment requires a lot of care, which are of extreme importance to the proposed results are attained with efficiency and, in this case, this planning was carried out with two years in advance so that there were no errors during the trial and analysis of data.

Planning before all the experimental phase was very strict, addressing in detail the economic aspects, such as: investments needed for the purchase of raw material (drawn steel wire), stopping the production process for the execution of the experiments (which represents shifts without production), maintenance of furnaces, tempering and measuring equipment to prevent failures during the trial, direct involvement of the Department of production planning for the correct Organization of the availability of inputs used in experiments (polymer, lead liquid to tempering, antioxidant, etc).

In this project, other costs were also very significant, such as: electrical energy, for heating phases of tempering furnaces use electricity for its operation (and energy costs are 
relatively high), use of the physical laboratory for mechanical tests (involving all the equipment and methods for investigation of results), high costs to employees for the execution of experiments and for carrying out the laboratory tests, logistics costs of inputs and the finished product to the appropriate places and also with the wages of a researcher who planned the whole experimental sequence and analyzed the data.

It was concluded that the statistical and optimization methods studied in academic environment often employed only on a small scale, research laboratories in universities, simulators eou apply perfectly in an industrial environment, solving complex problems and being of great value for future innovations in industries. However, the Organization in an industrial environment requires a lot of work in the planning phase and choice of appropriate methods that will be employed during and after the trial, because a mistake could mean the impossibility of realization of the project definitely, as are employed high financial resources in all stages of completion and it affects directly to the departments involved, because these must interact from planning and execution until data analysis.

\section{References}

[1] BARROS, A. D.; MOCELLIN, J. V. Análise da flutuação do gargalo em flow shop permutacional com tempos de setup assimétricos e dependentes da seqüência. Gestão \& Produção, São Paulo, v.11, n. 1, p. 101-108, Jan 2004.

[2] BLONDEAU R., MAYNIER, P. H.; DOLlET J., VIEILLARD, B. Mathematical model for the calculation of mechanical properties of low-alloy steel metallurgical products: a few examples of its applications. Bratec, Wisconsin, v. 48, n. 1, p. 3244-3246, oct 2000.

[3] CAllister JR., W. D.; RETHWISCH, D. G. Ciência e engenharia de materiais: Uma introdução. 8. ed. New York: LTC, 2012. $724 \mathrm{p}$.

[4] CAMARÃO, A. F. Um modelo para previsão de tensões residuais em cilindros de aço temperados por indução. 1998. $107 \mathrm{f}$. Thesis (doctorate in metallurgical engineering)- Escola de Engenharia de São Paulo, São Paulo, 1998.

[5] CHIAVERINI, V. Aços e Ferros Fundidos. 7. ed. São Paulo: Associação Brasileira de Metalurgia e Materiais, 2012. 600 p.

[6] CORREIA, E. A. S.; CARDOZA, J. A. S. Planejamento de experimentos no processo produtivo utilizando o método Taguchi. Gestão da Produção Operações e Sistemas, Bauru, v.6, n. 1, p. 55-66, jan 2011.

[7] GROSSELlE, F.; TIMELLI, G.; BONOLLO, F. Doe applied to microstructural and mechanical properties of $\mathrm{Al}-\mathrm{Si}-\mathrm{Cu}-$ Mg. Journal Materials Science and Engineering, Sydney, v. 527, n. 1, p. 3536-3545, oct 2010.

[8] GUNASEGARAM, D. R.; FARNSWORTH, D. J.;
NGUYENA, T. T. Identification of critical factors affecting shrinkage porosity in permanent mold casting using numerical simulations based on design of experiments. Journal of Materials Processing Technology, Sydney, v. 209, n. 1, p. 1209-1219, oct 2009.

[9] HODGSON, P. D.; GIBBS, R. K. A Mathematical Model to Predict the Mechanical Properties of Hot Rolled C-Mn and Microalloyed Steels". ISIJ International, Tokio, v. 32, n. 10, p. 32-50, jan 1992.

[10] HOLLAND, J. H. Adaptation in natural and artificial systems. 1. ed. Cambridge: MIT press, 1975. $500 \mathrm{p}$.

[11] JUNIOR, H. A. O. Projeto de filtros digitais e separação de fontes usando fuzzy adaptive simulated annealing. 2008. 140 f. Tese (Doutorado em Engenharia)- Universidade Federal do Rio de Janeiro, Rio de Janeiro, 2008.

[12] NETO, B. B.; SCARMINIO, I. S.; BRUNS, R. E. Como fazer experimentos: Pesquisa e Desenvolvimento na Ciência e na Indústria. 3. ed. Campinas: Unicamp, 2007. 480 p.

[13] PAULA, R. F. V. Fadiga de molas helicoidais de suspensão de automóveis. 2013. 145 f. Dissertação (Mestrado em Engenharia Mecânica)- Universidade Estadual Paulista, Guaratinguetá, 2013.

[14] RIBEIRO, L. P. P. G. Caracterização das Propriedades Mecânicas do Aço SAE 4140 após Diferentes Tratamentos de Têmpera e Revenido, 2006. 100 f. Dissertation (master's degree in metallurgical engineering)- Pontifícia Universidade Católica do Rio de Janeiro, Rio de Janeiro, 2006.

[15] ROSA, J. L.; ROBIN, A.; SILVA, M. B.; BALDAN, C. A.; PERES, M. P. Electrodeposition of copper on titanium wires: Taguchi experimental design approach. Journal of Materials Processing Technology, Sydney, v. 209, n. 1, p. 1181-1188, jan 2009.

[16] SACOMAN M. A. R.; Otimização de projetos utilizando GRG, Solver e Excel. In: CONGRESSO BRASILEIRO DE EDUCAÇÃO E ENGENHARIA, 1., 2012, Belém- Brasil, 2012. Impres. 1-12 p.

[17] SILVA, K. G. Uso de simulated annealing e algoritmo genético no problema da reconfiguração de uma rede de distribuição de energia elétrica. 2013. 140 f. Dissertação (Mestrado em Engenharia)- Universidade Federal do Rio Grande do Norte, Natal, 2013.

[18] YAMADA, Y. Material for springs. Japan Society of spring Engineers, Tokio, v. 1, n. 1, p. 377-384, dec 2007.

[19] YAMAMOTO, L. Uso de simulated annealing e algoritmo genético no problema da reconfiguração de uma rede de distribuição de energia elétrica. 2004. 100 f. Dissertação (Mestrado em Engenharia)-Universidade Federal do Paraná, Curitiba, 2004.

[20] ZINI, E. O. C. Algoritmo Genético especializado na resolução de problemas com variáveis contínuas e altamente restritos. 2009. 100 f. Dissertação (Mestrado em Engenharia Elétrica)Universidade Estadual Paulista, 2009. 